\title{
PENGELOLAAN SAMPAH RUMAH TANGGA DAN STOP BABS DI DESA WILAYAH KABUPATEN LEBAK BANTEN
}

\author{
Rusmana ${ }^{1}$, Yeyen Maryani², M. Iman Santoso ${ }^{3}$ \\ ${ }^{1,2,3}$ Universitas Sultan Ageng Tirtayasa
}

rusmana@untirta.ac.id, yeyen.maryani@untirta.ac.id,iman.santoso@untirta.ac.id

\begin{abstract}
Abstrak
Pengelolaan limbah rumah tangga yang tepat serta kebersihan dan kesehatan lingkungan melalui kebiasaan masyarakat stop buang air besar sembarangan dapat meningkatkan kesehatan masyarakat secara luas. Metode pelaksanaan dilakukan dengan workshop, sosialisasi, dan demo kepada masyarakat dengan pengelolaan limbah rumah tangga menggunakan konsep Pilah-Kumpul-Manfaat-Untung (PKMU) serta strategi pemicuan yang merupakan cara untuk mendorong perubahan perilaku higiene dan sanitasi atas kesadaraan sendiri dengan menyentuh perasaan, pola pikir, perilaku, dan kebiasaan individu atau masyarakat. Kegiatan pengabdian masyarakat ini dilaksanakan di Bumi Katineung Hotel Rangkasbitung pada tanggal 3 September 2021 dengan jumlah peserta 30 orang warga yang berasal dari 28 kecamatan di Kabupaten Lebak Propinsi Banten. Target capaian dalam kegiatan ini adalah peningkatan kemampuan warga dalam mengelola limbah rumah tangga, pemanfaatan limbah rumah tangga untuk media tanaman, pentingnya pengelola bank sampah, dan kebiasaan stop buang air besar sembarangan. Hasil dari kegiatan ini menunjukkan bahwa warga masyarakat sangat antusias dan potensial dapat memanfaatkan sampah rumah tangga sebagai bahan kompos atau mendaur ulang sampah, serta memahami pentingnya stop buang air besar sembarangan. Tindak lanjut dari kegiatan ini yaitu terbentuknya pengelola bank sampah di setiap desa dan pembiasaan stop buang air besar sembarangan dengan penyediaan/pembangunan jamban umum atau keluarga.
\end{abstract}

Kata Kunci : limbah rumah tangga, pengelolaan, BABS

\section{PENDAHULUAN}

Pengelolaan limbah dan persampahan merupakan salah satu masalah utama bagi pemerintah, baik di pusat, provinsi, kabupaten/kota, bahkan hingga tingkat desa. Pengelolaan limbah dan sampah ini tentunya bukan hanya menjadi kewajiban pemerintah semata, namun juga menjadi urusan kita bersama untuk senantiasa menjaga dan memelihara lingkungan yang bersih dari sampah dan limbah yang dihasilkan dari aktivitas yang dilakukan sehari-hari. Pengelolaan persampahan di Kabupaten Lebak Provinsi Banten yang dalam hal ini menjadi kewenangan dinas lingkungan hidup, dalam operasional pelayanannya belum dapat menjangkau pada 28 kecamatan yang ada di Kabupaten Lebak. Berdasarkan data pada tahun 2020 menyebutkan bahwa dari jumlah volume produksi sampah sebesar 202.099,04 ton, hanya sekitar 48.258,50 ton 
atau 23,88 persen sampah yang tertangani. Volume produksi sampah tersebut Sebagian besar berasal berasal dari limbah rumah tangga. Selain itu di Kabupaten Lebak masih ditemukan perilaku masyarakat yang masih buang air besar sembarangan yang dikenal dengan istilah dolbon, doli, atau rungsing. Terbatasnya sumber daya manusia serta sarana prasarana yang dimiliki dinas lingkungan hidup mengakibatkan kurangnya kemampuan dalam menangani sampah di seluruh wilayah Kabupaten Lebak.

Sampah rumah tangga merupakan sisasisa dari kegiatan sehari-hari yang dihasilkan masyarakat termasuk di dalamnya sisa-sisa bahan yang tidak dimanfaatkan atau dibuang. Kondisi ini lama kelamaan dapat meningkatkan jenis dan volume sampah sehingga dapat mencemari lingkungan dan menyebabkan berbagai masalah terutama masalah kesehatan bagi masyarakat. Permasalahan sampah sampai saat ini menjadi masalah yang belum dapat diatasi secara optimal dan masih perlu dilakukan pengelolaan terutama sampah yang dihasilkan dari rumah tangga. Pengelolaan sampah yang belum optimal dilakukan oleh masyarakat dan pemerintah daerah dapat mempengaruhi lingkungan dan kesehatan masyarakat sekitarnya serta menyebabkan kerugian, diantaranya: menimbulkan bau busuk, mengganggu keindahan, menyebabkan banjir, meningkatnya pemanasan iklim, memperburuk sanitasi lingkungan dan ancaman meningkatnya berbagai macam penyakit (Yudistirani, 2015).

Sampah yang tidak dikelola dengan baik berkontribusi terhadap keindahan lingkungan, pencemaran udara dan berdampak terhadap gangguan kesehatan masyarakat diantaranya penyakit pernafasan, diare, demam berdarah dan penyakit menular lainnya. Oleh karena itu masyarakat sebagai sumber penghasilkan sampah pada level rumah tangga harus diberdayakan dan dilibatkan secara aktif dalam pengelolaan sampah. Pengelolaan sampah harus dilakukan secara bersama-sama agar lebih optimal baik pihak pemerintah kabupaten, kecamatan, desa, dan masyarakat serta pihak akademisi dan berbagai pihak lainnya. Melalui keterlibatan masyarakat tersebut, maka mereka lebih mempercayai program pembangunan jika dilibatkan dalam suatu kegiatan dari mulai proses persiapan dan perencanaan serta sampai tahap pelaksanaan (Maulina, 2012).

Melalui kebijakan pembangunan yang tertuang dalam rpjmd tahun 2019-2024, penanganan persampahan telah menjadi bagian dari perwujudan misi ke-4 yaitu "mempertahankan kualitas lingkungan hidup" dengan tujuan terpeliharanya fungsi ruang dan kualitas lingkungan hidup serta indikator yang diukurnya adalah indeks kualitas lingkungan hidup (iklh) dengan target yang ingin dicapai pada tahun 2024 sebesar 53,53\%. Berdasarkan kondisi pengelolaan sampah yang ada dan juga sebagai upaya pencapaian agenda pembangunan dalam Rencana Pembangunan Jangka Menengah Daerah (RPJMD) Kabupaten Lebak, dipandang perlu adanya upaya-upaya inovatif, mulai dari penerapan kebijakan pemerintah sampai pada metode pengelolaan sampah atau limbah di tingkat rumah tangga yang merupakan satuan terkecil penghasil sampah setiap hari serta merubah perilaku masyarakat yang masih buang air besar sembarangan. Adapun upaya yang dilakukan pemerintah saat ini adalah dengan penerapan kebijakan pola pengurangan sampah yang akan diangkut ke Tempat Pembuangan Akhir (TPA).

Sanitasi Total Berbasis Masyarakat (STBM) merupakan pendekatan untuk mengubah perilaku higienis dan saniter melalui pemberdayaan masyarakat dengan cara pemicuan. Penyelenggaraan STBM bertujuan untuk mewujudkan perilaku masyarakat yang higienis dan saniter secara mandiri dalam rangka meningkatkan 
derajat kesehatan masyarakat yang setinggitingginya (Permenkes RI No. 3 Tahun 2014). Penyelenggaraan STBM dilakukan secara mandiri oleh masyarakat. STBM terdiri dari 5 pilar yaitu : (1) Stop Buang Air Besar Sembarangan (StopBABS). Stop buang air besar sembarangan adalah kondisi setiap individu dalam suatu komunitas tidak lagi melakukan perilaku buang air besar sembarangan yang berpotensi menularkan penyakit. Perilaku Stop-BABS diikuti dengan pemanfaatan sarana sanitasi yang saniter berupa jamban sehat; (2) Cuci Tangan Pakai Sabun (CTPS). Cuci tangan pakai sabun adalah perilaku cuci tangan menggunakan air bersih yang mengalir dan sabun. Sarana CTPS harus memiliki kriteria utama yaitu air bersih yang dapat dialirkan, sabun dan penampungan atau saluran air limbah yang aman; (3) Pengelolaan Air Minum dan Makanan Rumah Tangga (PAMM-RT). Pengelolaan air minum dan makanan rumah tangga adalah melakukan kegiatan mengelola air minum dan makanan di rumah tangga untuk memperbaiki dan menjaga kualitas air dari sumber air yang akan digunakan untuk air minum, serta untuk menerapkan prinsip higiene sanitasi pangan dalam proses pengelolaan makanan di rumah tangga; (4) Pengamanan Sampah Rumah Tangga (PS-RT). Pengamanan sampah rumah tangga adalah melakukan kegiatan pengelolaan sampah di rumah tangga dengan mengedepankan prinsip mengurangi, memakai ulang dan mendaur ulang. Tujuan dari pengamanan sampah rumah tangga yaitu untuk menghindari penyimpanan sampah rumah tangga dengan segera menangani sampah; dan (5) Pengamanan Limbah Cair Rumah Tangga (PLC-RT). Pengamanan limbah cair rumah tangga adalah melakukan kegiatan pengolahan limbah cair di rumah tangga yang berasal dari sisa kegiatan mencuci, kamar mandi dan dapur yang memenuhi standar baku mutu kesehatan lingkungan dan persyaratan kesehatan yang mampu memutus mata rantai penularan penyakit. Proses pengamanan limbah cair yang aman pada tingkat rumah tangga untuk menghindari terjadinya genangan air limbah yang berpotensi menimbulkan penyakit berbasis lingkungan.

Menurut Kemenkes RI (2012), program STBM dilaksanakan melalui proses pelembagaan tiga komponen sanitasi total (Gambar 1) yang merupakan satu kesatuan yang saling memengaruhi yaitu: a). Penciptaan lingkungan yang kondusif; b). Peningkatan kebutuhan dan permintaan sanitasi; dan c). Peningkatan penyediaan sanitasi.

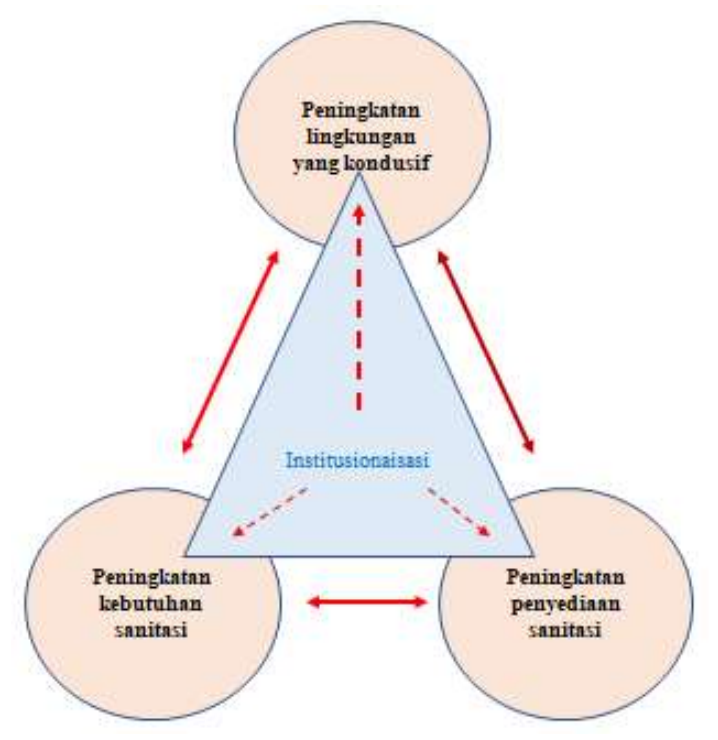

Gambar 1. Komponen sanitasi total

Ketiga komponen sanitasi total tersebut menjadi landasan strategi pelaksanaan untuk pencapaian 5 (lima) pilar STBM.

\section{a. Penciptaan Lingkungan yang Kondusif}

Komponen ini mencakup advokasi kepada para pemimpin Pemerintah, Pemerintah Daerah dan pemangku kepentingan dalam membangun komitmen bersama untuk melembagakan kegiatan pendekatan STBM yang diharapkan akan menghasilkan: Komitmen pemerintah daerah menyediakan sumber daya untuk melaksanakan pendekatan STBM menyediakan anggaran untuk penguatan intitusi ; Kebijakan dan peraturan daerah mengenai program sanitasi seperti SK Bupati, Perda, RPJMP, Renstra, dan lain-lain; Terbentuknya lembaga koordinasi yang mengarusutamakan sektor sanitasi, menghasilkan peningkatan anggaran sanitasi daerah, koordinasi sumber daya dari 
pemerintah maupun non-pemerintah; Adanya tenaga fasilitator, pelatih STBM dan kegiatan peningkatan kapasitas; Adanya sistem pemantauan hasil kinerja dan proses pengelolaan pembelajaran.

\section{b. Peningkatan Kebutuhan dan Permintaan Sanitasi}

Komponen peningkatan kebutuhan sanitasi merupakan upaya sistematis untuk mendapatkan perubahan perilaku yang higienis dan saniter, berupa: Pemicuan perubahan perilaku; Promosi dan kampanye perubahan perilaku higiene dan sanitasi secara langsung; Penyampaian pesan melalui media massa dan media komunikasi lainnya; Mengembangkan komitmen masyarakat dalam perubahan perilaku; Memfasilitasi terbentuknya komite/tim kerja masyarakat; Mengembangkan mekanisme penghargaan terhadap masyarakat/institusi melalui mekanisme kompetisi dan benchmark kinerja daerah.

c. Peningkatan Penyediaan Sanitasi

Peningkatan penyediaan sanitasi yang secara khusus diprioritaskan untuk meningkatkan dan mengembangkan percepatan penyediaan akses dan layanan sanitasi yang layak dalam rangka membuka dan mengembangkan pasar sanitasi perdesaan, yaitu: Mengembangkan opsi teknologi sarana sanitasi yang sesuai kebutuhan dan terjangkau; Menciptakan dan memperkuat jejaring pasar sanitasi perdesaan; Mengembangkan kapasitas pelaku pasar sanitasi termasuk wirausaha sanitasi lokal; Mempromosikan pelaku usaha sanitasi dalam rangka memberikan akses pelaku usaha sanitasi lokal ke potensi pasar (permintaan) sanitasi on site.

\section{METODE}

Metode pelaksanaan acara ini dilakukan dengan workshop dan penyampaian ide melalui kegiatan sosialisasi dan demo kepada masyarakat bertempat di Bumi Katineung Hotel Rangkasbitung Kabupaten Lebak Provinsi Banten tanggal 3 September 2021 selama sehari (fullday) dengan para peserta adalah warga masyarakat yang berasal dari berbagai wilayah di Kabupaten Lebak dari 28 kecamatan.

Strategi kegiatan berupa strategi pemicuan yang merupakan cara untuk mendorong perubahan perilaku higiene dan sanitasi individu atau masyarakat atas kesadaraan sendiri dengan menyentuh perasaan, pola pikir, perilaku, dan kebiasaan individu atau masyarakat yaitu dengan Pendidikan Kesehatan kepada masyarakat. Adapun tujuan, manfaat dan dampak kegiatan yang diharapkan dapat dirasakan oleh kegiatan ini adalah: (1) Menyadarkan masyarakat desa di wilayah Kabupaten Lebak tentang kondisi buruk perilaku sanitasi dan hygiene mereka dan bahaya yang akan ditimbulkan (antara lain bahwa dengan kebiasaan BAB sembarangan dan di fasilitas yang tidak layak, melalui berbagai media kontaminasi, mereka bisa makan kotoran sesama dan terancam berbagai penyakit); (2) Memicu perubahan secara individu dan kolektif masyarakat desa di wilayah Kabupaten Lebak, antara lain untuk tidak lagi BAB di sembarang tempat atau di fasilitas yang tidak layak sesegera mungkin; (3) Memicu rasa solidaritas sosial atau kegotongroyongan masyarakat desa di wilayah Kabupaten Lebak untuk mengatasi permasalahan sanitasi karena merupakan tanggung jawab bersama, individu, dan komunitas; (4) Masyarakat desa di wilayah Kabupaten Lebak menjadi tahu bahwa membuat jamban sehat tidak harus mahal, ada beberapa pilihan/opsi jamban yang dapat mereka pilih sesuai kemampuannya; (5) Masyarakat desa di wilayah Kabupaten Lebak menjadi tahu, paham, dan terampil melaksanakan Metode Pilah-Kumpul-Manfaat-Untung (PKMU) merupakan solusi yang ditawarkan untuk membantu mengurangi volume sampah dan daur ulang sampah sehingga dapat digunakan oleh masyarakat sebagai pupuk atau kompos sebagai media penanaman tanaman obat keluarga.

\section{HASIL DAN PEMBAHASAN}

\section{Pengelolaan Sampah Rumah Tangga}

Dalam pengelolaan sampah rumah tangga peran serta masyarakat sangat besar pengaruhnya untuk keberhasilan program pengelolaan sampah berbasis masyarakat. Kehadiran peserta dalam pengabdian ini menunjukkan antusias mereka dan harapan untuk dapat mengetahui, memahami, serta memiliki kerampilan dalam pengelolaan sampah dan sanitasi lingkungan sebagaimana ditunjukkan pada Gambar 2. 


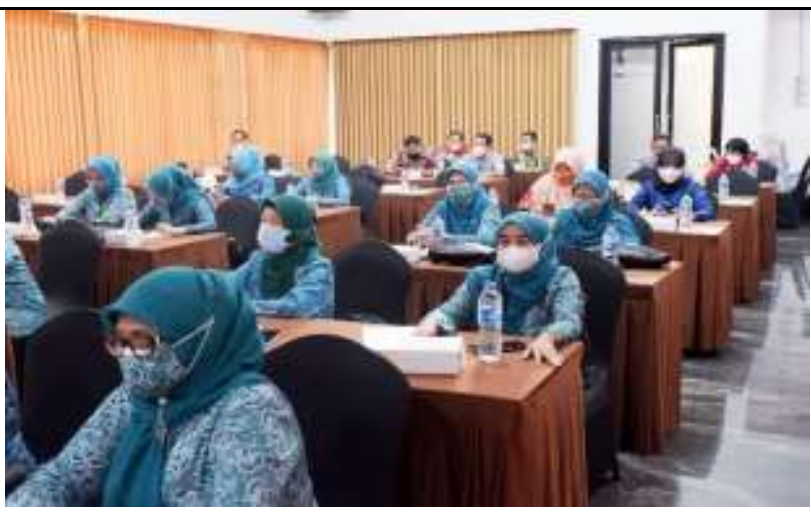

Gambar 2. Peserta penyuluhan pengelolaan limbah rumah tangga dan stop BABS di wilayah Kabupaten Lebak

Metode pendekatan dengan paradigma Pilah-Kumpul-Manfaat-Untung (PKMU) dapat dipahami masyarakat dan akan berdampak terhadap pengurangan sampah yang akan dibuang ke tempat sampah akhir (TPA). Melalui metode ini sampah sudah mulai dilakukan pemilahan pada level rumah tangga sehingga cara ini membantu mengurangi volume sampah terutama bahan-bahan yang tidak mudah terurai di lingkungan seperti plastik, kaleng, dan lainnya. Selain itu, melalui pembentukan bankbank sampah di lingkungan permukiman, dimana sampah-sampah yang dihasilkan rumah tangga dilakukan pemilahan terlebih dahulu sebelum dibuang ke tempat penampungan sementara, dan untuk sampah yang dapat dimanfaatkan kembali atau didaur ulang akan ditampung oleh bank sampah, sehingga masih memiliki nilai ekonomi. Dengan demikian selain berdampak ekonomi, jumlah timbulan sampah yang diangkut sampai ke tempat pembuangan akhir diharapkan dapat pula dikurangi secara signifikan dan dapat menjaga keseimbangan daya dukung dan fungsi TPA dalam menjaga Kesehatan manusia dan lingkungannya. Menurut Huber-Humer dan Lechner (2011), TPA yang berkelanjutan didefinisikan sebagai suatu sistem yang ditujukan untuk mencapai keseimbangan yang dapat diterima oleh lingkungan dalam satu generasi (30-40 tahun). Disaat penghalang fisik pada TPA gagal untuk menghambat pencemaran, pelepasan emisi mengakibatkan tingginya beban lingkungan yang harus diatasi untuk menghindari ancaman terhadap kesehatan manusia dan lingkungan. Berdasarkan tanya jawab selama kegiatan, para peserta menunjukkan pengetahuan dan pemahaman yang meningkat dengan banyaknya pertanyaan terkait PKMU dan SBABS serta motivasi untuk mengimplementasikannya. Mereka meminta untuk ada tindaklanjut kegiatan melalui praktek nyata dan terus mendapat bimbingan baik dari perguruan tinggi, pemerintah daerah, maupun pihak-pihak lainnya.

Kegiatan pengabdian ini juga merupakan upaya dalam menumbuhkan kebiasaan masyarakat dalam mengelola sampah agar mencapai kesadaran dan kebiasaan yang tumbuh dan menjadi kebutuhan masyarakat agar kebiasaan pengelolaan sampah ini berkelanjutan. Menurut Mahyudin (2014) keberlanjutan tidak akan bisa berjalan tanpa adanya kemauan dan kesadaran dari masyarakat, selama ini indikator pemenuhan kebutuhan masyarakat dan peningkatan standar ekonomi dan perkembangan kemajuan telah dijadikan dasar alasan dalam meningkatnya jumlah sampah yang harus ditampung lingkungan. Fokus pengelolaan sampah baru tertuju pada masalah teknis, dampak lingkungan, ekonomi dan sosial. Tapi akar permasalahan utama yaitu permasalahan paradigma dan pola pikir belum menjadi pertimbangan banyak pihak dalam mengelola sampah.

Para peserta penyuluhan dalam diskusi menyampaikan bahwa sampah rumah tangga sebagian besar adalah sampah limbah rumah tangga berupa bahan organik. Pengurangan sampah rumah tangga yang dibuang ke TPA melalui pemilahan sampah di level rumah tangga (yang pada umumya sebagian besar merupakan sampah organik) dapat digunakan untuk menjadi bahan pupuk organik untuk dimanfaatkan sebagai pupuk berbagai tanaman. Sebagian besar sampah rumah tangga di berbagai daerah pun didominasi oleh bahan organik sebagaimana ditunjukkan oleh hasil penelitian Yustiani, dkk. (2019) yang mendapatkan beberapa temuan yaitu: Rata-rata timbulan sampah per orang per hari di Desa Babakan adalah 0,134 kg. Komposisi sampah organik mendominasi hingga $70,5 \%$, sedangkan anorganik sebanyak $29,5 \%$. Jenis sampah terbanyak dalam kelompok sampah anorganik adalah plastik. 
Kebiasaan masyarakat buang sampah sembarangan termasuk buang sampah ke sungai perlu disadarkan melalui upaya perubahan perilaku. Kebanyakan masyarakat masih memahami sampah sebagai barang yang tidak diinginkan sehingga harus segera dibuang. Persepsi masyarakat mengenai sampah inilah yang menjadikan sampah hanya berpindah tempat dan akhirnya menumpuk pada satu tempat saja, misalnya tempat pembuangan akhir (TPA). Apabila sampah tidak dikelola dengan baik maka akan berdampak pada masalah kesehatan berupa timbulnya penyakit diare, typus, kolera demam berdarah dan penyakit lainnya. Pembuangan sampah di tempat yang tidak semestinya juga bisa mengakibatkan persoalan sosial bahkan lebih jauh lagi bisa berdampak pada masalah ekonomi. Misalkan sampah yang dibuang di sungai bisa mengakibatkan banjir dan tentunya kualitas air pun menjadi menurun padahal di bagian hilir sungai banyak masyarakat yang memanfaatkan air untuk berbagai kebutuhannya. Penurunan kualitas air sungai akibat sampah telah diteliti oleh Peny, dkk. (2021), yang menunjukkan terjadinya penurunan kualitas air Sungai Martapura antara hulu dan hilir sungai yang diakibatkan aktivitas masyarakat di bantaran Sungai Martapura. Walaupun perilaku masyarakat masuk pada kategori sedang, namun dari hasil penelitian sebanyak $68,04 \%$ responden membuang sampahnya ke sungai dan $52,58 \%$ masyarakat menggunakan sungai sebagai tempat MCK, hal inilah yang menyebabkan menurunnya kualitas air Sungai Martapura. Hal ini dilakukan secara turun temurun dimana $88,66 \%$ masyarakat mengaku membuang sampah di sungai sudah dilakukan sejak mereka masih kecil. Hal tersebut membuktikan bahwa akibat masyarakat buang sampah ke sungai akan sangat merugikan baik dari segi kesehatan maupun ekonomi.

Dengan meningkatnya pengetahuan dan pemahaman serta motivasi peserta kegiatan pengabdian untuk mengimplementasikannya terkait PKMU perlu dilakukan tindak lanjut kegiatan praktek PKMU dengan bimbingan baik perguruan tinggi, pemerintah daerah, maupun pihak terkait lainnya untuk dilakukan secara terjadwal dan berkelanjutan. Hal ini menuntut untuk semua pihak (PT, Pemda, pihak terkait lainnya) selalu aktif berkordinasi dan merencanakan kegiatan secara bersama.

\section{Stop BABS (SBABS)}

Upaya perubahan perilaku masyarakat yang masih buang air besar sembarangan perlu terus dilakukan melalui pemberian pengetahuan, pemahaman, penyadaran masyarakat sehingga dapat berubah menjadi kebiasaan buang air besar di jamban keluarga dan stop kebiasaan buang air besar sembarangan. Perilaku masyarakat merupakan gabungan dari pengetahuan, sikap, dan tindakan masyarakat. Pengetahuan yang baik dengan pemberian informasi secara khusus dan terus menerus akan mempengaruhi perilaku hidup sehat seseorang dan juga sebaliknya pengetahuan yang kurang dapat mengakibatkan penerapan Perilaku Hidup Bersih dan Sehat (PHBS) yang kurang. Selanjutnya jika dilihat dari tingkat pengetahuan dengan penerapan PHBS keluarga dengan tingkat persentase paling tinggi yaitu tingkat pengetahuan kurang dengan penerapan PHBS paling banyak yaitu sehat madya hal ini menunjukkan bahwa dengan tingkat pengetahuan yang kurang dapat mempengaruhi kurangnya penerapan PHBS dikeluarga. Hasil penelitian yang dilakukan oleh Carolina, dkk. (2016), menunjukkan bahwa terdapat hubungan yang bermakna antara tingkat pengetahuan dengan penerapan perilaku hidup bersih dan sehat. Hal ini membuktikan bahwa pengetahuan sangat berperan penting dalam penerapan perilaku hidup bersih dan sehat.

Banyak faktor yang mempengaruhi pelaksanaan program sanitasi total berbasis masyarakat pilar pertama (SBABS) selain kesadaran, kemauan, dan rasa butuh yang masih rendah sehingga di Kabupaten Lebak masih banyak masyarakat yang BABS. Hasil penelitian Fatonah (2016) menunjukkan bahwa faktor-faktor yang mempengaruhi rendahnya partisipasi masyarakat dalam pelaksanaan program sanitasi total berbasis masyarakat pilar pertama (SBABS) di Desa Purwosari Kecamatan Sayung Kabupaten Demak Tahun 2015 adalah faktor internal dan faktor eksternal. Faktor internal yang meliputi mata pencaharian/ pekerjaan masyarakat, pendapatan, pengetahuan. Sedangkan untuk kepercayaan terhadap fenomena tertentu tidak mempengaruhi 
partisipasi masyarakat karena yang berpengaruh adalah perilaku dari masyarakat tersebut. Faktor eksternal yang mempengaruhi adalah stakeholder yang ikut terlibat dalam program yaitu pemerintah daerah, perangkat desa, dan fasilitator. Hal ini memberikan petunjuk bahwa Gerakan menyadarkan masyarakat harus dilakukan secara bersama-sama oleh semua pihak dan dilakukan secara terus menerus berkelanjutan. Menurut Maksuk dkk. (2020), untuk keberlanjutan program pengelolaan sampah maka perlu dilakukan dengan pembentukan pengelola Bank Sampah sebagai salah satu alternatif solusi bagi pemerintah dan masyarakat untuk mengurangi peningkatan volume sampah yang semakin tidak terkendali. Selain memberikan dampak positif bagi lingkungan, dalam proses pengelolaannya, bank sampah memiliki mekanisme relasi dan jaringan sosial yang bernilai ekonomis. Rekomendasi dari hasil kegiatan pengabdian masyarakat ini adalah: 1). Perlu adanya kerjasama yang baik antara perguruan tinggi (dosen), aparat pemerintah Kabaupaten Lebak dan masyarakat setempat agar kegiatan pengelolaan sampah rumah tangga dapat berjalan dengan baik dan berkelanjutan; 2). Dalam rangka pengembangan bank sampah ke depan pemerintah perlu memfasilitasi dalam bentuk sosialisasi, pemberian dana hibah atau pinjaman modal, dan pelibatan pihak swasta, melalui Corporate Social Responsibility (CSR), untuk percepatan dalam implementasi di masyarakat; dan 3). Pengetahuan dan keterampilan masyarakat dalam pengelolaan sampah serta pembiasaan SBABS perlu terus dilaksanakan secara berkelanjutan untuk dapat menjangkau seluruh desa yang tersebar di Kabupaten Lebak.

\section{KESIMPULAN}

Pengelolaan sampah merupakan kegiatan yang harus dimulai dari rumah tangga dalam mengurangi volume sampah dan pemanfaatan kembali sisa-sisa sayuran, buah dan bahan organik lainnya untuk kompos. Metode Pilah-KumpulManfaat-Untung (PKMU) merupakan solusi yang ditawarkan untuk membantu mengurangi volume sampah dan daur ulang sampah sehingga dapat digunakan oleh masyarakat sebagai pupuk atau kompos sebagai media penanaman tanaman obat keluarga. Kegiatan ini dapat menguntungkan masyarakat yaitu melalui pembentukan pengelola bank sampah yang dikelola oleh masyarakat sendiri, sehingga hasilnya dapat dinikmati oleh masyarakat.

Pembiasaan SBABS diperlukan kesadaran dan harus menjadi kebutuhan seluruh warga masyarakat dan perlu terus dilakukan upaya penyuluhan berkelanjutan. Penyuluhan tentang kebiasaan Stop Buang Air Besar Sembarangan (SBABS) yang diselenggarakan, mendapat sambutan dan antusias yang sangat baik dari peserta. Keadaan ini dapat dilihat dari kehadiran peserta yang berasal dari berbagai desa sebanyak 30 orang dan pertanyaan peserta yang bervariasi terkait SBABS. Hasil kegiatan ini akan membekali para peserta dalam mengimplementasikan dan mendesiminasikan kepada warga lainnya dalam SBABS, yang secara berkelanjutan akan membawa kepada kesehatan masyarakat secara luas yang lebih baik.

\section{SARAN}

Pembiasaan masyarakat Kabupaten Lebak Provinsi Banten untuk berperilaku hidup bersih dan sehat melalui penyadaran dengan peningkatan pengetahuan, pemahaman, keterampilan dalam pengelolaan sampah rumah tangga dan SBABS masih perlu dilakukan dan melibatkan berbagai pihak secara berkelanjutan.

\section{UCAPAN TERIMAKASIH}

Ucapan terimakasih disampaikan kepada pemerintah daerah Kabupaten Lebak atas koordinasinya serta JARI (Jejaring Alumni Returning Experts Indonesia) sebagai pelaksana bersama sehingga acara pengabdian kepada masyarakat di Kabupaten Lebak Provinsi Banten.dapat berjalan lancar.

\section{REFERENSI}

Carolina,P., Meilitha C., Rizki M. L. (2016). Hubungan Tingkat Pengetahuan dan Sumber Informasi dengan Penerapan Perilaku Hidup Bersih dan Sehat (PHBS) pada Keluarga di Wilayah Kerja Pustu 
Pahandut Seberang Kota Palangkaraya Raya Tahun 2016. EnviroScienteae 12(3):330-337.

Fatonah, N.S. (2016). Partisipasi Masyarakat dalam Pelaksanaan Program Sanitasi Total Berbasis Masyarakat Pilar Pertama (Stop BABS) di Desa Purwosari Kecamatan Sayung Kabupaten Demak. Skripsi. Jurusan Ilmu Kesehatan Masyarakat Fakultas Ilmu Keolahragaan Universitas Negeri Semarang.

Huber-Humer M. and Lechner, P. (2011). Science Direct Waste Management Journal. Sustainable landfilling or sustainable society without landfilling? Waste Management. 31:1427-1428.

Kemenkes RI. (2012). Manlaknis STBM Sanitasi Total Berbasis Masyarakat. Pedoman Pelaksanaan Teknis STBM Tahun 2012. Kementrian Kesehatan Republik Indonesia Direktorat Jenderal Penyehatan Lingkungan dan Penyehatan Lingkungan Direktorat Penyehatan Lingkungan.

Mahyudin, R.P. (2014). Strategi Pengelolaan Sampah Berkelanjutan. EnviroScienteae 10 (1):33-40

Maksuk, Lukman, dan Kumalasari, I. (2020). Pemberdayaan Petugas Kesehatan dan Kader Puskesmas dalam Pengolahan Limbah Rumah Tangga Sebagai Kompos: Jurnal Pengabdian Masyarakat Kesehatan, 6(2), 75-79. https://doi.org/10.33023/jpm.v6i2.587

Maulina, AS, (2012). Identifikasi Partisipasi Masyarakat dalam Pemilahan Sampah di Kecamatan Cimahi Utara Serta Faktor yang Mempengaruhinya. Jurnal Perencanaan Wilayah dan Kota. 23 (3):177-196.

Penny, L., U. Bijaksana, R. Yunita, D. Itta. (2012) Kajian perilaku masyarakat membuang sampah di bantaran sungai martapura terhadap lingkungan perairan. EnviroScienteae 8(3): 117-126

Permenkes RI. (2014). Peraturan Menteri Kesehatan Republik Indonesia Nomor 3 Tahun 2014 Tentang Sanitasi Total Berbasis Masyarakat. Kementrian Kesehatan Republik Indonesia. Jakarta.

Yudistirani, SA, Syaufina, L., Mulatsih, S. (2015). Desain Sistem Pengelolaan Sampah Melalui Pemilahan Sampah Organik dan Anorganik Berdasarkan Persepsi Ibu-ibu Rumah Tangga. Konversi. 4 (2):29-42.

Yustiani, Y.M., Anni R., dan Elva A. (2019). Konsep Pengelolaan Sampah di Desa Babakan Kabupaten Bandung. EnviroScienteae 15(1):121-126. 